\author{
Professor Victor DRAGOTĂ, PhD \\ E-mail: victor.dragota@fin.ase.ro \\ Dragoş Ştefan OPREA, PhD (Corresponding author) \\ E-mail: dragos.oprea@fin.ase.ro \\ Laura OBREJA BRAŞOVEANU, PhD \\ E-mail: laura.brasoveanu@fin.ase.ro \\ Department of Finance and CEFIMO \\ The Bucharest University of Economic Studies
}

\title{
MARKET EFFICIENCY, PREDICTIONS AND RETURNS
}

\begin{abstract}
The most part of the financial literature agree that the information contained in different financial variables is related somehow to the stock market indexes. Some theories state that the stock market index predicts the future performance of the economy, whereas others sustain that it is linked to the release of new information or it has a lagged reaction to it.

This paper investigates the relation between a Romanian stock market index and some (especially macroeconomic) variables in the period between February 2002 to December 2013, considering for possible contemporaneous, lagged and anticipated relations.

The results suggest that the variation of the index is mostly associated with the synchronous levels of the indicators. Moreover, stock market index return is better explained by the future levels than the ones for the past levels of indicators.

Keywords: stockmarket return, information, Efficient Market Hypothesis, macroeconomic factors, Romania.
\end{abstract}

\section{JEL Classification: G12, G14.}

\section{Introduction}

Stock market returns' determinants are analyzed in different contexts. Among other explanations, economic theory links the evolutions of security indexes with macroeconomic factors (e.g., Fama 1981,Naifar 2016). Stock market return may anticipate future levels of some macroeconomic variables (Mankiw 2010). A synchronous dependence can be related to an instant reaction to the news (see the event studies literature). Finally, security indexes might react with a lag (see the tests rejecting the Efficient Market Hypothesis, thereafter, EMH, in weak form, in the terminology of Fama 1970).

Our paper tests if the stock market index return is more associated with the contemporaneous, lagged or ex ante levels of some selected (mostly macroeconomic)indicators. We analyze the capital market's ability to correctly 
Victor Dragotă, Dragoş Ştefan Oprea, Laura Obreja Braşoveanu

valuate the assets'price and to forecast (or at least react to) new information. We perform this analysis on the Romanian stock market through one of its indexes. Single-country studies can provide a better understanding of some markets' behaviour. Differences between countries occur, and sometimes are consistent, even for apparently similar cases (see Dragotă and Țilică 2014). These differences can have an impact on the performance of international diversified portfolios, in estimating the equity risk premium, etc. Moreover, the number of the financial assets' determinant factors is potentially very large. In this context, identifying the impact factors for the Romanian capital market can be considered also a relevant contribution.

We prove that the synchronous levels of variables have the most important impact on the stock index return. From this perspective, new information seems to be more of a surprise than an (already) anticipated fact. A large part of literature analyses the impact of the publication of different financial indicators using event studies (see Section 2). Our approach is different. For some variables, the capital market might anticipate the future events (and news), but, for others, the capital market might react to the news with a lag. Agents might have different channels for in searching for information and, even, interpret it differently.

The remainder of the paper is structured as follows. In Section 2, the theoretical background and tested hypotheses are discussed. In Section 3, we present the methodology. Data are described in Section 4. The main results are presented in Section 5 and discussed in Section 6. Section 7 concludes.

\section{Theoretical background and tested hypotheses}

Financial theory and practice generally accept that prices reflect more or less the available information. This assumption is common to EMH and to the challengers of this theory (Fama 1970; Vozlyublennaia 2014).

Even if the significance of different indicators is supposed to be fully understood by investors, an issue is how is the information (contained in these indicators) included in prices. It can be instantly integrated (by reacting at the moment of the public release of the information), incorporated with a delay (with a lag, after the levels of indicators are publicly released), or predicted (in this case, investors no longer react at the moment in which the indicators are publicly released). If a market predicts a large part of future information, respectively future information is integrated in actual prices, financial resources would be allocated more appropriately in the economy and presumably the systematic abnormal earnings reached only by some investors, due to the improper allocation of these financial resources invested the other ones, would be reduced. A contemporaneous ${ }^{1}$ reaction of stock indexes to different information can lead to a fair game, even if in this case the total surprise to new events is synonymous with an incapacity of

1 A synonymous term for contemporaneous can be simultaneous. We use these two terms interchangeable, but we prefer the first one, as in Fama (1981). 
prediction. The lagged reaction can be translated as an invitation for arbitrageurs to reach systematic abnormal earnings, but it can be considered preferable to a nonreaction to information.

A large part of EMH literature is devoted to the analysis of investor's ability to earn systematic abnormal returns (e.g., see the surveys of Fama 1970, Malkiel 2003, Dragotă and Țilică 2014). The analysis of the coincidence between prices and fundamental values, even recognized by the early study of Fama (1970), was less privileged in finance. However, some studies focus exactly on this topic (e.g., Dragotă and Mitrică 2004 for Romania).

If a market is efficient, assets' prices should integrate the public information (Fama 1970). Moreover, the investors should make credible predictions about the evolutions of prices' determinants. Even if the most part of the events can be predicted in a reasonable manner (and they are already included in prices), the unanticipated ones (the news) would have an impact on the stock prices (Malkiel 2003), and, from here, also, on the market indexes.

However, even if the financial theory agrees with the integration of future information in prices, the empirical examination of this principle is difficult. For instance, supposing the market can expect some future events, how long before can they be anticipated? Our paper does not analyze the impact of the release of new information, based on event studies. Event studies analyze the impact of different news releases on stocks or indexes returns. Different event studies performed for the case of Romania prove that the current information is integrated in prices (see, for instance, Țilică et al. 2012). It seems that sometimes the present information can be instantly integrated in prices, in parallel with the existence of the possibility to reach systematic abnormal earnings using technical analysis. In addition, the stock prices might be affected also by some unexpected events related to some factors. Our main purpose is to examine if the stock prices are more connected to present, past or future values of some indicators. In our approach, we consider future values of the indicators the values recorded by the indicators in the future (and not anticipations made using different instruments, simulations, etc.). In other words, comparative to the present level of one indicator $\left(\mathrm{I}_{\mathrm{t}}\right)$, its future level (after $l$ lags) is the effective (realized) level of this indicator at the moment $t+l\left(\mathrm{I}_{\mathrm{t}+1}\right)$. We test the hypothesis that factor $j$ at time $(t-l), t$ and $(t+l)$ may determine the market return at time $t$ (with $l$ the length of the lag/lead period). Therefore, we consider the possible lagged, simultaneous and leaded (ex ante) effects of the macro economic variables. The evolution of the market index (MI) in these three situations is depicted in Figure 1, which provides the theoretical background for our three tested hypotheses.

One important notice should be made. The future level of one indicator is not the same as the anticipated level of this indicator; it would be strange if somebody would think it is, because it would have as implication that peoples, in general, know perfectly the future. In this paper, we consider future level of indicator as a clue about the investors' forecasting abilities. 
Victor Dragotă, Dragoş Ştefan Oprea, Laura Obreja Braşoveanu

In this context, the following question arises: "Do the stock markets forecast the future levels of macroeconomic indicators?" Mankiw (2010, p. 264) states: "the stock market reflects expectations about future economic conditions because stock market investors bid up prices when they expect companies to be profitable. An increase in stock prices indicates that investors expect the economy to grow rapidly; a decrease in stock prices indicates that investors expect an economic slowdown." As such, the dependence between current level of market index return and the realized values of some macroeconomic indicators, in the future (after they are recorded), can be considered as a reflection of the indexes' ability of prediction.

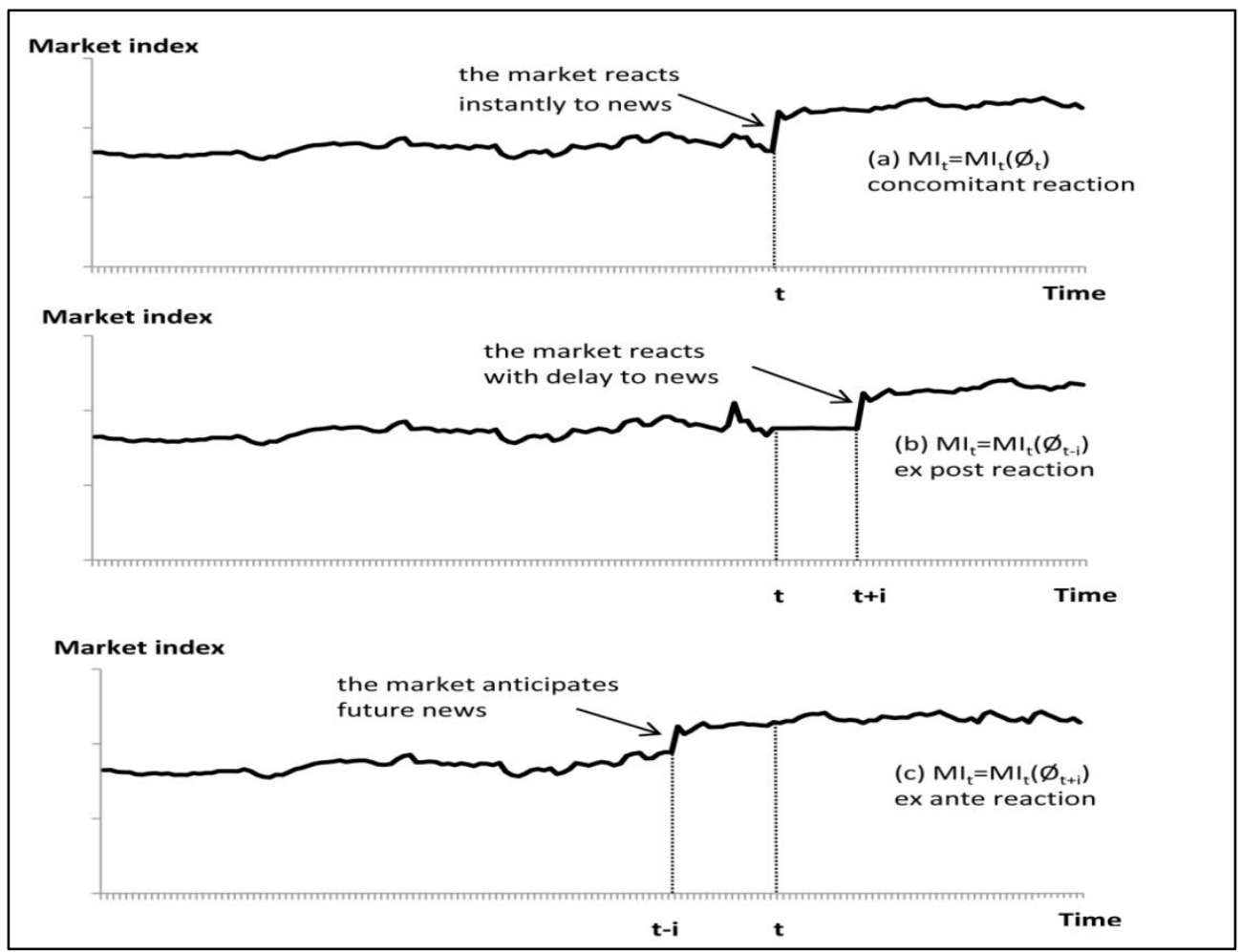

Figure 1: This figure presents the theoretical evolution of market index in time, for three scenarios. At moment $t$, new information is provided to the public. $\emptyset_{t}$ is the stock of information at time $t$. The theoretical evolution of the market indexes is different. In the case: (a) new information is integrated instantly (synchronous reaction); (b) the market has a lagged reaction to information; (c) market reacts before the release of the future information (in this study, it is assumed that the market anticipates the future information) (leaded impact, ex ante reaction).

A large number of empirical studies test the impact of different macroeconomic factors on stock returns and prices, using Ordinary Least Squares (for example, see Peiro 2016) and other research methods (e.g., Vector Autoregressive Model and Cointegration in Suhaibu et al. 2017; Vector Error Correction Model in Patra and 
Poshakwale 2006) of time series analysis, on data from both developed and emerging economies.

Many macroeconomic factors can be taken into account as possible determinant factors of stock returns (see Table 1). The concept of 'news' is very comprehensive. If the level of one indicator is published, this is not entirely new information. "News is, by definition, unpredictable" (Malkiel 2003). Event studies describe the capital market reaction to news. The realized return is compared with the expected normal return and, thus, an abnormal return can be calculated. In the absence of predicted future events, the anticipated normal return is close to 0 . Therefore, the market reaction is determined only by news, if there are no predicted events. However, if the investors make some anticipations, the release of a new data for some indicator can be divided into two components: one already included in prices, and the other one, which is new information.

Ina perfect efficient market, prices $(P)$ can be considered as equal with intrinsic values of the assets ( $V$ ) (Dragotă and Mitrică 2004). If the market has a relative degree of inefficiency, a bias from this value $(B)$ can occur. However, both $V$ and $B$ are functions of available information $(\Phi)$. Therefore, the price of one asset or the level of market index at one moment, $t, P_{t}$ can be written as:

$$
P_{t}=P_{t}\left(V_{t} / \phi_{t}, B_{t} / \phi_{t}\right)
$$

Theoretically, the available information at one moment, 0 , can be written as:

$$
\phi_{0}=\int_{-\infty}^{0} \varphi_{t} d t+\int_{0}^{\infty} E_{0}\left(\varphi_{t}\right) d t
$$

with $\varphi_{\mathrm{t}}$ the new information which occurs at the moment $t$ (an adjustment in the available information), where $E_{0}\left(\varphi_{t}\right)$ is the expectations (at moment 0 ) of new information $\varphi_{t}$ (for the future).

At each moment $t, \varphi_{t}$ is a combined effect of different news $\left(i_{t}\right)$.Let assume that the news $i_{t}$ (for which we use as proxy the relative change of a financial indicator, $I_{t}$, respectively: $i_{t}=\frac{I_{t}-I_{t-1}}{I_{t-1}}$ ) occurs.

Then, on an efficient market, $\phi_{t}=\phi_{t}\left(i_{t}\right)$, but in general, $\phi_{t} \neq \phi_{t}\left(i_{t-l}\right)$, with $l>0$. However, it can be noticed that only a part of the indicator's variation can be considered new information ,because some predictions regarding the indicator variation, made by investors in the past, are already integrated in prices, and only some adjustments are made at moment t. The most part of the financial variables are flow indicators (and not stock indicators), so at least one important part of the indicator's variation is already known before it is published or released in the media. The synchronous impact of the macroeconomic variables can be explained by the instantaneous integration of new information, but also, in a degree, by the incapacity of prediction, because the market reacts only when the new information occurs (the largest part of new information is a surprise). From here, the first tested hypothesis is:

H1: The market index reacts simultaneously to new information.

Regarding this first hypothesis, it can be argued that the most appropriate test for the instant integration of information in prices should be the event study. Indeed, 
Victor Dragotă, Dragoş Ştefan Oprea, Laura Obreja Braşoveanu

event studies are a more powerful instrument for testing the instant reaction of prices. However, due to the data availability, we use the monthly variation of prices. Even less accurate from a methodological viewpoint, our approach can be preferable if we consider that not all the agents on the market have equal and instant access to the release of new information. For instance, Peress (2014) argues that itis plausible to recognize that, unlike institutional investors, the retail investors do not have access to professional news services such as Reuters or Bloomberg. The diffusion of information through local media can be slowed down by events like newspaper strikes (Peress 2014); therefore, a gradual integration of news can be expected.

If the markets have a low degree of efficiency, still the information will be integrated in prices, at least by arbitrageurs and by noisy traders through mimetic behaviour (Lakonishok et al. 1994, etc.). Based on a mimetic behaviour, it can still be expected that the noisy traders will imitate the behaviour of the well-informed and rational investors, so the information will be somehow integrated into prices. However, as long as investors are assumed to have different available information, caused by the distribution channel used, some information can be integrated in prices with a temporal lag (Peress 2014). Moreover, Hong and Stein (2007) stress the idea that some investors can be characterized by limited attention: it is assumed that these investors pay attention only to a subset of available and relevant information because they are cognitively overloaded. Under this hypothesis, these investors may be distracted for some reasons and react to new information after the disappearance of the distraction cause. The longer this temporal lag is, the lower is the degree of market efficiency. The integration of information in prices, taking into account the behaviour of noisy traders and arbitrageurs, is also approached by behavioural finance. However, even if the market does not react instantly and correctly to the new information, our purpose is to test if at least the market has a reaction at all, even slower. In a different context, a lagged reaction can be interpreted as a sign of the extrapolating nature of investors' expectations: investors consider the past as the best proxy for the future evolutions (Greenwood andShleifer2014). In this case, $\phi_{t}=\phi_{t}\left(i_{t-l}\right)$, with $1>0$. From here, the second tested hypothesis is:

H2: The market index reacts with a lag to new information.

If prices react before events occur (respectively, an ex-ante reaction), it might be interpreted that investors have already included in prices their expectations about these future events (Mankiw, 2010, p. 264).In this context, it could be interesting to determine the average ex-ante period for which the investors forecast these future events. However, this ex ante reaction could also be interpreted as information leakage. In this scenario, some investors obtain privileged information as trade based on it before the information is publicly released. The impact of this phenomenon can be higher in the cases of little capital markets. In this case, $\phi_{t}=$ $\phi_{t}\left(i_{t+l}\right)$, with $l>0$. From here, the third tested hypothesis is: 


\section{H3: The market index anticipates the future information.}

We test if the market index return $\left(\mathrm{RM}_{\mathrm{t}}\right)$ is associated with flows of information $(\Phi)$, considering synchronous dependence ${ }^{2}\left(\mathrm{RM}_{\mathrm{t}}=\mathrm{RM}_{\mathrm{t}}\left(\Phi_{\mathrm{t}}\right)\right)$, a lagged dependence $\left(\mathrm{RM}_{\mathrm{t}}=\mathrm{RM}_{\mathrm{t}}\left(\Phi_{\mathrm{t}-1}\right)\right)$, and a leaded (ex-ante) dependence $\left(\mathrm{RM}_{\mathrm{t}}=\mathrm{RM}_{\mathrm{t}}\left(\Phi_{\mathrm{t}+1}\right)\right)$, with 1 being the length of the lag (or lead). The flow of information is a vector of factors. These factors can be macroeconomic or not (even if in this study we focus on the macroeconomic ones), and they can be considered as a part of the information flow.

Supposing that one variable recorded at moment $t$ is determined by another variable recorded in the past $(t-l$, with lag) or in the future $(t+l$, with lead), finding the most appropriate lag or lead is challenging. From the beginning, it has to be accepted that the publication of indicators (conventionally recorded as monthly values) is not entirely 'news' (some of information is already known by investors). For instance, new information (e.g., changes in some indicators) occurs daily, but they are recorded at a monthly level. Some variables are recorded at smaller than monthly periods. However, in these cases, we consider monthly variations to ensure the comparability along the variables. Moreover, during the month, some news with positive, but also negative impact can be disclosed but the cumulative effect might result in a (conventional) non-variation, similar to the no new information case. Keeping in mind these limitations, in our study we take into account lags/leads from 0 (that means the stock market index return and the macroeconomic variable are synchronous) to 3 months.

\section{Methodology}

We run several linear multiple regressions in which the return of the Romanian stock market index $\left(\mathrm{RM}_{\mathrm{t}}\right)$ is explained by contemporaneous, ex-ante or, respectively lagged factors, respectively:

(i) for the synchronous impact:

(ii) for the lagged impact:

$$
R M_{t}=\alpha+\sum_{j=1}^{n} \beta_{j} \cdot F_{j t}+u_{t}
$$

$$
R M_{t}=\alpha+\sum_{j=1}^{n} \beta_{j} \cdot F_{j t-l}+u_{t}
$$

(iii) for the anticipative reaction:

\footnotetext{
${ }^{2}$ Our prudence in interpreting our results derives from the significance of statistical indicators. For instance, by definition, a correlation between $\mathrm{X}$ and $\mathrm{Y}$ can be explained by a dependence between $\mathrm{X}$ and $\mathrm{Y}$, a dependence between $\mathrm{Y}$ and $\mathrm{X}$, or by a dependence of both $\mathrm{X}$ and $\mathrm{Y}$, on one hand, and another variable, let it be $\mathrm{Z}$.
} 
Victor Dragotă, Dragoş Ştefan Oprea, Laura Obreja Braşoveanu

$$
R M_{t}=\alpha+\sum_{j=1}^{n} \beta_{j} \cdot F_{j t+l}+u_{t}
$$

In these equations: $\alpha$ is the intercept, $\beta_{j}$ - the sensitivity of stock market index return to a change of factor $j, R M_{t}$ - the realized (effective, historical) return of the stock market index at time $t, F_{j t}$ - the determinant factor $j$ at time $t, l$ - the lag or the lead $(l=0,1,2,3), n$ - the total number of factors and $u_{t}$ - an error term.

In accordance with the objective of our study, we did not include in the same regression independent variables recorded at different moments, even if that option would determine a higher adjusted $\mathrm{R}^{2}$ (and a more meaningful result in the search for the best regression model, explaining the determining factors of market index return). Thus, we are not concerned about the predictive power of our models; we are only interested if the market index return is explained more by the synchronous, by the lagged, or by the future values of the independent variables. In the same line, one common instrument to improve the quality of the regressions is to use dummy variables (for instance, a dummy for the crisis period). Given the objective of our paper - to test the ability of prediction of the stock market index this approach would affect the precision of our analysis.

Considering the correlation between some determinant factors, we run several regressions. To avoid multicollinearity, we include in a regression only the uncorrelated or weakly correlated variables (in the interval $[-0.3,+0.3]$ ).

We test the presence of heteroscedasticity, using White test. In addition, we test serial correlation in the error terms during the estimation of regressions, using the Breusch-Godfrey Lagrange multiplier test for 1, 6 and 12 lags. We also examine if the relationship between the Romanian index return and the explanatory variables is linear or not by using the Ramsey RESET test.

\section{Data}

We consider as dependent variable the monthly return of the Bucharest Exchange Trading-Composite Index (BET-C) from February 2002 to December 2013. BETC was launched in 16 April 1998 and was calculated until 22 June 2014. In 23 June 2014 the BET-C index was replaced by the Bucharest Exchange Trading Plus Index (BET Plus). We preferred to make our analysis using BET-C and not BET Plus because of its longer period of existence. It isa weighted market capitalization index, including all the companies listed on the Bucharest Stock Exchange (hereafter BSE) regulated market, on the $\mathrm{I}^{\text {st }}$ and $\mathrm{II}^{\text {nd }}$ categories, with the exception of the Romanian closed end funds resulting from the privatization process ${ }^{3}$. The closing levels of BET-C are retrieved from BSE website- www.bvb.ro. The realized return of the stock market index in month $t\left(R M_{t}\right)$ is calculated as the

\footnotetext{
${ }^{3}$ Some minor changes in the composition of BET-C index occurred during the analyzed period, but their impact is insignificant for our analysis.
} 
Market Efficiency, Predictions and Returns

relative change between two consecutive months of the stock market index $\left(R I_{t}\right.$, $\left.R I_{t-1}\right)$ :

$$
R M_{t}=\frac{R I_{t}-R I_{t-1}}{R I_{t-1}}
$$

Table 1: Factors considered as possible determinants of the Romanian market return

\begin{tabular}{|c|c|c|c|c|}
\hline Symbol & Factor & \begin{tabular}{|l|} 
Relevant studies \\
\end{tabular} & Definition and source & Observations \\
\hline IPG & $\begin{array}{l}\text { The growth rate of } \\
\text { industrial production }\end{array}$ & $\begin{array}{l}\text { Fama (1981), Boyd et al. (2005), Peiro } \\
\text { (2016), Suhaibu et al. (2017) }\end{array}$ & $\begin{array}{l}\text { Calculated based on the Industrial } \\
\text { Production Index (source: INSSE) }\end{array}$ & \\
\hline EPG & $\begin{array}{l}\text { The growth rate of } \\
\text { exports }\end{array}$ & Asprem (1989) & $\begin{array}{l}\text { Calculated based on the value of } \\
\text { exports (source: NBR) }\end{array}$ & \\
\hline IMG & $\begin{array}{l}\text { The growth rate of } \\
\text { imports }\end{array}$ & Asprem (1989) & $\begin{array}{l}\text { Calculated based on the value of } \\
\text { imports (source: NBR) }\end{array}$ & \\
\hline BTG & $\begin{array}{l}\text { The growth rate of trade } \\
\text { deficit }\end{array}$ & Hanousek et al. (2009) & $\begin{array}{l}\text { Calculated based on the value of } \\
\text { exports and imports (source: NBR) }\end{array}$ & $\begin{array}{l}\text { The balance of trade records only negative } \\
\text { observations for the analysed period. Thus, } \\
\text { the growth rate of balance of trade } \\
\text { represents the growth rate of trade deficit. }\end{array}$ \\
\hline FEG & $\begin{array}{l}\text { The growth rate of } \\
\text { foreign exchange } \\
\text { reserves }\end{array}$ & Pajuste et al. (2000) & $\begin{array}{l}\text { Calculated based on the foreign } \\
\text { exchange reserves at the end of the } \\
\text { month (source: NBR) }\end{array}$ & \\
\hline UNE & Unemployment rate & Asprem (1989), Boyd et al. (2005) & $\begin{array}{l}\text { Unemployment rate at the end of the } \\
\text { month (source: NBR) }\end{array}$ & \\
\hline INF & The inflation rate & Suhaibu et al. (2017) & $\begin{array}{l}\text { Calculated based on the Consumer } \\
\text { Price Index (source: INSSE) }\end{array}$ & \\
\hline MSG & $\begin{array}{l}\text { The growth rate of } \\
\text { money supply }\end{array}$ & Suhaibu et al. (2017) & $\begin{array}{l}\text { Calculated based on the monetary } \\
\text { aggregate M1 at the end of the month } \\
\text { (source: NBR) }\end{array}$ & \\
\hline INT & Interest rate & Peiro (2016), Suhaibu et al. (2017) & $\begin{array}{l}\begin{array}{l}\text { Romanian Interbank Offer Rate at } 3 \\
\text { months at the end of the month } \\
\text { (source: NBR) }\end{array} \\
\end{array}$ & \\
\hline EXG & $\begin{array}{l}\text { The growth rate of } \\
\text { exchange rate }\end{array}$ & $\begin{array}{l}\text { Pajuste et al. (2000), Anghelache et al. } \\
\text { (2014), Peiro (2016) }\end{array}$ & \begin{tabular}{|l|} 
Calculated based on the end of month \\
spot exchange rate RON/EUR \\
(source: NBR)
\end{tabular} & $\begin{array}{l}\text { We use only the RON/EUR exchange rate } \\
\text { because from } 2002 \text { to } 2011 \text { the international } \\
\text { transactions of Romania were mainly with } \\
\text { the EU members. For the whole period, the } \\
\text { exports to the EU members had an annual } \\
\text { average of } 73 \% \text { from total exports of } \\
\text { Romania and the EU members' imports had } \\
\text { an annual average of } 69 \% \text { from the total } \\
\text { imports. }\end{array}$ \\
\hline OIG & $\begin{array}{l}\text { The growth rate of oil } \\
\text { price }\end{array}$ & $\begin{array}{l}\text { Anghelache et al. (2014), Naifar } \\
\text { (2016) }\end{array}$ & \begin{tabular}{|l|} 
Calculated based on the end of month \\
spot oil price West Texas \\
Intermediate (WTI) (source: U.S. \\
Energy Information Administration - \\
www.eya.gov)
\end{tabular} & \\
\hline XAG & $\begin{array}{l}\text { The growth rate of gold } \\
\text { price }\end{array}$ & Anghelache et al. (2014) & $\begin{array}{l}\text { Calculated based on the end of month } \\
\text { spot gold price - USD/troy ounce of } \\
\text { gold (source: The World Gold } \\
\text { Council - http://www.gold.org) }\end{array}$ & \\
\hline MVL & Market volatility & Welch and Goyal (2008) & $\begin{array}{l}\text { Standard deviation of the BET-C } \\
\text { index. }\end{array}$ & $\begin{array}{l}\text { Monthly volatility is computed as the } \\
\text { standard deviation of the daily BET-C } \\
\text { index return in each month from our period. }\end{array}$ \\
\hline LIQ & Market liquidity & Patra and Poshakwale (2006) & \begin{tabular}{|l|} 
Based on the monthly total traded \\
value and the monthly average \\
market capitalization
\end{tabular} & $\begin{array}{l}\text { Monthly turnover is computed as the ratio } \\
\text { between the monthly total traded value and } \\
\text { the monthly average market capitalization. }\end{array}$ \\
\hline WIR & $\begin{array}{l}\text { The return of MSCI } \\
\text { ACWI index }\end{array}$ & Hunter (2006) & $\begin{array}{l}\text { MSCI ACWI is an index designed to } \\
\text { measure the equity market } \\
\text { performance of developed and } \\
\text { emerging markets (source: } \mathrm{MSCI} \text { ). }\end{array}$ & $\begin{array}{l}\text { The monthly rate of return is computed as } \\
\text { the percentage change in the last index level } \\
\text { of two consecutive months. }\end{array}$ \\
\hline EIR & $\begin{array}{l}\text { The return of MSCI } \\
\text { Emerging Markets } \\
\text { index }\end{array}$ & $\begin{array}{l}\text { Pajuste et al. (2000), Anghelache et al. } \\
(2014)\end{array}$ & $\begin{array}{l}\text { MSCI Emerging Markets is an index } \\
\text { designed to measure the equity } \\
\text { market performance of emerging } \\
\text { markets (source: MSCI). }\end{array}$ & $\begin{array}{l}\text { The monthly rate of return is computed as } \\
\text { the percentage change in the last index level } \\
\text { of two consecutive months. }\end{array}$ \\
\hline DIR & $\begin{array}{l}\text { The return of MSCI } \\
\text { World index }\end{array}$ & Pajuste et al. (2000) & $\begin{array}{l}\text { MSCI World is an index designed to } \\
\text { measure the equity market } \\
\text { performance of developed markets } \\
\text { (source: MSCI). }\end{array}$ & $\begin{array}{l}\text { The monthly rate of return is computed as } \\
\text { the percentage change in the last index level } \\
\text { of two consecutive months. }\end{array}$ \\
\hline $\mathrm{CCG}$ & $\begin{array}{l}\text { The growth rate of } \\
\text { consumer lack of } \\
\text { confidence }\end{array}$ & Schmeling (2009) & \begin{tabular}{|l|}
$\begin{array}{l}\text { Calculated based on level of } \\
\text { Consumer Confidence Index (source: } \\
\text { DG ECFIN) }\end{array}$ \\
\end{tabular} & $\begin{array}{l}\text { The Consumer Confidence Index records } \\
\text { only negative observations for the analysed } \\
\text { period. Thus, the indicator reflects the } \\
\text { growth of the consumer lack of confidence } \\
\text { in the analysed period. }\end{array}$ \\
\hline
\end{tabular}


Victor Dragotă, Dragoş Ştefan Oprea, Laura Obreja Braşoveanu

Notes: All of the indicators are calculated based on the monthly levels of variables. In this table: Romanian National Institute of Statistics (INSSE), website www.insse.ro; National Bank of Romania (NBR), website: www.bnro.ro; Morgan Stanley Capital International (MSCI), website: www.msci.com. Directorate Generale for Economic and Financial Affairs (DG ECFIN), website:

http://ec.europa.eu/economy_finance/db_indicators/surveys/time_series/index_en.htm.

In accordance with the previous literature on stock market return determinants, we consider as possible determinants the indicators presented in Table 1. Some of them are macroeconomic factors (e.g., the growth rates for industrial production, exports, or imports), while others are not (e.g., the growth rate of consumer lack of confidence). All of them are calculated based on the monthly levels of variables. We performed the Augmented Dickey-Fuller (ADF) and Phillips-Perron (PP) tests for unit root. We also test the stationarity using the Kwiatkowski-PhillipsSchmidt-Shin (KPSS) test, obtaining compatible results. All the series are stationary. The statistics point to departure from normality for most of the macroeconomic variables. However, these results are similar to those reported by other studies (e.g., Naifar 2016) ${ }^{4}$.

\section{Results}

We perform 93 regressions (12 for synchronous, 45 for lags, 36 for leads) of all possible combinations of explanatory variables. Due to space restrictions, Table 2 contains selected regressions considering the maximum $\mathrm{R}$-squared for synchronous, lagged and lead impact of the explanatory factors on market index return (all regressions are available upon request ${ }^{5}$ ).

Table 2: Market index return as effect of explanatory variables - selected regression for synchronous, lagged and lead impact

\begin{tabular}{|c|c|c|c|c|c|c|c|}
\hline \multirow[t]{2}{*}{ Factors } & \multirow{2}{*}{$\begin{array}{c}\text { Synchronous } \\
\text { impact }\end{array}$} & \multicolumn{3}{|c|}{ Lagged impact } & \multicolumn{3}{|c|}{ Ex ante (lead) impact } \\
\hline & & 1 month & 2 months & 3 months & 1 month & 2 months & 3 months \\
\hline C & $-0.1247 * * *$ & $-0.0871 * * *$ & $-0.0831 *$ & -0.0416 & $-0.1500^{* * *:}$ & $-0.1418 *$ & $0.1306 * * *$ \\
\hline IPG & & 0.0960 & & & -0.0447 & 0.2092** & \\
\hline \multicolumn{8}{|l|}{ EPG } \\
\hline IMG & $-0.0934 *$ & & 0.0589 & -0.0915 & & & 0.0500 \\
\hline BTG & & -0.0079 & & & $0.0095 * *$ & 0.0044 & \\
\hline FEG & 0.0032 & -0.0715 & $-0.3175^{*}$ & -0.1264 & $0.5393^{* * * * *}$ & $0.3357^{*}$ & $\begin{array}{l}-0.0024 \\
\end{array}$ \\
\hline UNE & $1.7590 * * * *$ & $1.7870 * * * *$ & $1.6052 * * *$ & $0.9224 *$ & $1.6672^{* * * *}$ & $1.8101 * * *$ & $1.9918 * *: *$ \\
\hline \multicolumn{8}{|l|}{ INF } \\
\hline MSG & 0.0777 & $0.3513 * * *$ & 0.1040 & $-0.3042 * * *$ & $-0.1560 *$ & $0.2337 * *$ & 0.1811 \\
\hline \multicolumn{8}{|l|}{ INT } \\
\hline EXG & $-0.7578 * * *$ & $-0.7163 * *$ & $\begin{array}{l}-0.2609 \\
\end{array}$ & $1.0902 * *$ & 0.3183 & 0.0556 & -0.4514 \\
\hline OIG & & $0.1861^{* * *}$ & & 0.1048 & & $0.1464 *$ & \\
\hline
\end{tabular}

${ }^{4}$ Data are available from the authors and will be publicly available on their ResearchGate profiles.

${ }^{5}$ They will be publicly available from the authors (see the authors' ResearchGate profiles). 
Market Efficiency, Predictions and Returns

\begin{tabular}{|l|c|c|c|c|c|c|c|}
\hline XAG & -0.0599 & $-\mathbf{0 . 3 4 0 8} * * *$ & 0.0814 & -0.0219 & 0.0718 & -0.0611 & 0.0609 \\
\hline MVL & & -1.1777 & & $\mathbf{- 2 . 3 5 1 9} *$ & & -0.1056 & \\
\hline LIQ & $\mathbf{3 . 4 9 5 7 * *}$ & 0.9069 & 0.3338 & $\mathbf{3 . 8 9 3 2} * *$ & $\mathbf{6 . 3 6 6 8} * * *$ & $\mathbf{4 . 2 2 7 8} * *$ & $\mathbf{3 . 1 3 8 7} *$ \\
\hline WIR & & & & & & & \\
\hline EIR & $\mathbf{0 . 6 6 4 5} * * *$ & & 0.0952 & & & & $\mathbf{- 0 . 2 3 1 5 *}$ \\
\hline DIR & -0.0422 & & -0.0711 & & & & -0.0733 \\
\hline CCG & $48.11 \%$ & $25.64 \%$ & $7.89 \%$ & $14.17 \%$ & $28.25 \%$ & $21.01 \%$ & $10.01 \%$ \\
\hline Adj. R-squared & 0.8332 & 0.4681 & $4.7082 * *$ & $7.6244 * * *$ & 0.5137 & 0.7340 & 2.2464 \\
\hline $\begin{array}{l}\text { Breusch-Godfrey LM } \\
\text { test with 1 lag }\end{array}$ & $1.8284 *$ & 1.1532 & $2.1559 *$ & $1.8690^{*}$ & 1.6118 & 1.6066 & 1.7852 \\
\hline $\begin{array}{l}\text { Breusch-Godfrey LM } \\
\text { test with 6 lag }\end{array}$ & 1.0257 & 0.7061 & 1.4279 & 1.2230 & 1.5198 & 1.5055 & 1.3847 \\
\hline $\begin{array}{l}\text { Breusch-Godfrey LM } \\
\text { test with 12 lag }\end{array}$ & $3.1895 * * *$ & 0.8493 & $3.0947 * * *$ & $1.9428 *$ & $3.5715 * * *$ & 1.3303 & 1.5953 \\
\hline $\begin{array}{l}\text { White Heteroskedasticity } \\
\text { test }\end{array}$ & -1.2273 & -0.4069 & -0.2524 & $-4.7417 * * *$ & -0.9782 & -3.6368 & $-7.7401 * *$ \\
\hline $\begin{array}{l}\text { Ramsey RESET test } \\
\text { FITTED^2 }\end{array}$ & & & & & $\mathbf{0 . 3 6 8 1 *}$ & & \\
\hline
\end{tabular}

Notes: IPG represents the monthly growth rate of industrial production. EPG is the monthly growth rate of exports. IMG represents the monthly growth rate of imports. BTG is the monthly balance of trade growth. FEG is the monthly growth rate of foreign currency reserves. UNE represents the monthly unemployment rate. INF is the monthly inflation rate. MSG represents the monthly growth rate of money supply. INT is the monthly interest rate (the Romanian Interbank Offer Rate at 3 months). EXG is the monthly growth rate of exchange rate. OIG represents the monthly growth rate of oil price. XAG is the monthly growth rate of gold price. MVL is the monthly market volatility. LIQ represents the monthly market liquidity. WIR is the monthly return of MSCI ACWI index. EIR represents the monthly rate of return of MSCI Emerging Markets index. DIR is the monthly rate of return of MSCI World index. CCG is the monthly growth rate of consumer lack of confidence. RM is the monthly return of Romanian stock market index.

We test for the presence of heteroscedasticity and serial correlation in the error terms during the estimation of the regression. The heteroscedasticity is tested by the White heteroscedasticity test (White 1980) and the serial correlation is verified by the Breusch-Godfrey Lagrange multiplier test (Breusch 1978; Godfrey 1978) for 1, 6 and 12 lags. If we detect only the heteroscedasticity, we apply the correction proposed by White (1980) and if errors are autocorrelated, we apply the correction proposed by Newey - West (1987) in order to compute t-statistics (see Brooks 2008, p. 152). We also examined if the relationship between the Romanian index return and the explanatory variables is linear or not, by using Ramsey RESET test (Ramsey 1969) where FITTED^2 represents the square of the fitted values. $* * *, * *$ and $*$ indicates significance at the $1 \%, 5 \%$ and $10 \%$ levels, respectively. Source: Own processing.

We include here a synthesis of the results (see Table 3). The signs of the variables' coefficients remain stable in all regressions.

It is interesting to note that some variables show to have only a lagged influence on the return when we estimate the multiple regressions: inflation rate, growth rate of gold price, and growth rate of consumer lack of confidence, prove to have only an ex-post effect on the return. These results support the hypothesis that investors react only to previous levels of these indicators. Inflation rate has a positive impact on stock market return. Suhaibu et al. (2017) found a positive impact of the inflation rate on equity index return for 12 African countries. 
Victor Dragotă, Dragoş Ştefan Oprea, Laura Obreja Braşoveanu

Table 3: Synthesis of the factors that determine the index return based on multiple regressions

\begin{tabular}{|c|c|c|c|c|c|c|c|}
\hline Factors & \multicolumn{3}{|c|}{ Lagged impact } & \multirow{2}{*}{$\begin{array}{c}\text { Contemporaneous } \\
\text { impact } \\
\end{array}$} & \multicolumn{3}{|c|}{ Ex ante impact } \\
\hline & Lag 1 & Lag 2 & Lag 3 & & Lead 1 & Lead 2 & Lead 3 \\
\hline IPG & & & & - & & + & \\
\hline EPG & + & & - & - & & + & \\
\hline $\mathrm{IMG}$ & & & & - & & + & \\
\hline BTG & - & & - & & + & + & \\
\hline FEG & & - & & & + & + & \\
\hline UNE & + & + & + & + & + & + & + \\
\hline INF & & + & & & & & \\
\hline MSG & + & + & - & + & - & + & \\
\hline INT & + & + & + & + & + & & \\
\hline EXG & - & & + & - & & & \\
\hline $\mathrm{OIG}$ & + & & & + & + & + & \\
\hline $\mathrm{XAG}$ & - & & & & & & \\
\hline MVL & - & & - & - & - & & \\
\hline LIQ & & & + & + & + & + & + \\
\hline WIR & + & & + & + & + & & \\
\hline EIR & + & & + & + & & & - \\
\hline DIR & + & & + & + & + & & \\
\hline $\mathrm{CCG}$ & & - & & & & & \\
\hline $\mathrm{RM}$ & + & & & & & & \\
\hline $\begin{array}{c}\text { Highest } \\
\text { Adjusted } \\
\mathrm{R}^{2}\end{array}$ & $25.64 \%$ & $7.89 \%$ & $14.17 \%$ & $48.11 \%$ & $28.25 \%$ & $21.01 \%$ & $10.01 \%$ \\
\hline
\end{tabular}

Notes: IPG represents the growth rate of industrial production. EPG is the growth rate of exports. IMG represents the growth rate of imports. BTG is the balance of trade growth. FEG is the growth rate of foreign currency reserves. UNE represents the unemployment rate. INF is the inflation rate. MSG represents the growth rate of money supply. INT is the interest rate (the Romanian Interbank Offer Rate at 3 months). EXG is the growth rate of exchange rate. OIG represents the growth rate of oil price. XAG is the growth rate of gold price. MVL is the market volatility. LIQ represents the market liquidity. WIR is the return of MSCI ACWI index. EIR represents the rate of return of MSCI Emerging Markets index. DIR is the rate of return of MSCI World index. CCG is the growth rate of consumer lack of confidence. RM is the return of Romanian stock market index. All indicators are calculated monthly.

Source: Own processing

The growth rate of gold price has a negative impact on stock market return; this might be evidence for the hypothesis that investors consider gold as an alternative investment. From a contemporaneous perspective, Anghelache et al. (2014) find that the gold returns did not have any significant correlation with the four CEE index returns from the Czech Republic, Hungary, Poland and Romania. Further, Anghelache et al. (2014) observed that the growth rate of gold price has a lag impact on the index return of Poland and Romania, but the sign of the influence is not reported.

The growth rate of consumer lack of confidence has a negative effect on stock market return, which suggests that the confidence (the optimism or the pessimism) 
in the economy influences the consumption and saving attitude, therefore affecting the economy and the capital market return. Schmeling (2009), using a panel regression analysis, reported that consumer confidence index and future stock market returns are negatively related. The database includes 18 countries (US, Japan, Australia, New Zeeland and 14 European countries). Similar evidences are reported for individual markets; eleven of eighteen markets registered a significantly negative consumer confidence index-return relation. However, the negative relation is stronger in case of Japan, Italy and Germany.

The growth rate of industrial production and the growth rate of imports have both contemporaneous and ex-ante impacts on the stock market return. These indicators have a negative contemporaneous impact, but a positive leaded effect. The anticipated economic growth might stimulate the investors' interest in capital market. The negative relation between the current economic growth and market index return is difficult to interpret. It can be considered as a negative correction of the investor's expectations once the public information is released, due probably to the initial over-optimistic anticipations. Suhaibu et al. (2017) found a positive impact of the GDP growth rate on equity index return for 12 African countries.

The growth rates of trade deficit and of foreign exchange reserves have both expost and ex-ante impact on stock market return. These indicators have a negative lagged impact, but a positive leaded effect. The positive ex-ante impact of the growth rate of foreign exchange reserves might be evidence that investors consider their increase as a sign of financial stability (Cruz and Walters 2008).

Other variables have both a synchronous and ex-ante effect: growth rate of industrial production, growth rate of imports, growth rate of money supply, growth rate of exchange rate.

An important part of the variables has ex-post, contemporaneous, and ex-ante effects on stock market return: growth rate of exports, unemployment rate, growth rate of money supply, interest rate, growth rate of exchange rate, growth rate of oil price, market volatility, market liquidity, return of MSCI ACWI index, return of MSCI Emerging Markets index, return of MSCI World index. This supports the hypothesis that investors react to the previous, current and future level of these indicators, which might represent evidence for sustaining that investors integrate this information ex-post and simultaneously, but also having some predictive abilities regarding these indicators. The changes in sign (e.g., EPG) can suggest combined effects for predictions, simultaneous and lagged reactions.

The impact of exports growth rate is difficult to interpret (growth rate of exports +/- lag, -sync, +lead). The positive coefficient might be evidence for the conclusion that the increased export is interpreted as a raise of the national production and the economic activity, generating an increase of the stock market return.

The growth rate of unemployment rate has a positive effect, which is counterintuitive. Generally, the unemployment is interpreted as a sign of uncertainty, therefore reducing the appetite for capital market investments. However, Boyd et al. (2005) find that, on average, an announcement of rising unemployment is good news for stocks during economic expansions and bad news 
Victor Dragotă, Dragoş Ştefan Oprea, Laura Obreja Braşoveanu

during economic contractions, which can explain our result (the period covered by our database include the period of crisis). In the same line, the interest rate has a positive impact on market index return (as in Naifar 2016, for Dow Jones Islamic Market Index).

The coefficient for the growth rate of oil price is positive and significant, which sustains that current change in oil price has a positive influence on the current index return (as in Naifar 2016).

The market volatility has a negative impact on market index return; this result might be a support for the hypothesis that a higher volatility is interpreted as a proxy for uncertainty regarding the future, determining the investors' pessimism, a decrease in market index. The result can be connected with the interpretation provided by Naifar (2016).

The market liquidity has a positive impact on the stock market return. The lack of liquidity is in general perceived by the investors as determining a discount in assets valuation, so an increase in market liquidity can be interpreted as an increase in the market's attractivity. This positive relation with market return is found both for synchronous and ex ante levels of the market liquidity. Less important, we found a relation between liquidity (lag $=3$ months) and market return. One possible explanation is that investors are making their prediction considering the past as the best predictor (Greenwood and Shleifer 2014).

The growth rates of the indexes (MSCI ACWI index, MSCI Emerging Markets index, MSCI World index) have a positive impact on the stock market return - this might be considered evidence for the Romanian capital market's reaction to other capital markets (at least in part, similar to Anghelache et al. 2014, which find that Romanian Index BET is correlated with the MSCI emergent market index).

We can note that in some cases the impact of some macroeconomics is counterintuitive. However, taking into account that the investors could have overly optimistic/pessimistic expectations of the indicators, the price of stocks will be mispricing. It is possible that each mispricing will eventually be corrected so that one should observe that an overly optimistic/pessimistic expectation is followed by a negative/positive contemporaneous impact on stock returns and if the mispricing is persistent, the lag impact is also negative/positive. Nevertheless, the sign of the contemporaneous reaction and lagged impact could be different showing the incapacity of the investors to evaluate in a proper manner the set of available information.

Interestingly, in some cases, we detected non-linear dependences between market index return and some explanatory factors. Finding and explaining these dependences can be a new direction for future studies. Another interesting issue is the highest level of adjusted $\mathrm{R}^{2}$ for the 3 months lag, comparatively to the one for 2 months lag. It could suggest that the investors are more interested in the last quarter levels of indicators, comparatively to the levels recorded two months ago. 
Market Efficiency, Predictions and Returns

\section{Discussion}

Comparing the results reported, some interesting conclusions can be drawn. It seems that the current information is the most important in explaining stock market returns. The adjusted $\mathrm{R}^{2}$ of the regressions for the contemporaneous impact are higher than those for lagged impact and ex ante impact. The regressions for contemporaneous impact have greater adjusted $\mathrm{R}^{2}$. The most important part of information seems to be integrated in prices simultaneously to the release of indicators.

The past and the future information appear to have a relative similar strength in explaining the returns. However, the highest level of adjusted $\mathrm{R}^{2}$ is recorded for the anticipated levels of indicators. These combined results are in line with previous studies on market efficiency of the Romanian capital market, concerned about the possibility of reaching systematic abnormal earnings, using investment strategies based on past returns. Initially, some studies reject EMH (e.g., Dragotă and Mitrică 2004). However, some more recent studies reveal an improvement in the level of informational efficiency. Dragotă and Țilică (2014), using different tests, revealed that the EMH in its classical weak form can be rejected for some assets or indexes, but not for all the cases: the level of efficiency is depending on the tests used and on the period of analysis. It seems that past information still has an impact on market index level. From this point of view, the lagged impact of some variables appears to confirm that the information is slowly integrated in prices, in line with the tests regarding the possibility of reaching systematic abnormal earnings based on past prices (Vozlyublennaia 2014). The dependence between past levels of indicators and the current level of market index can be also explained by the use of these past values as the best predictors for future values of indicators (Greenwood and Shleifer 2014).

This result can be also connected with the degree of market efficiency in an international comparative context. According with Dragotă and Țilică (2014), the level of market efficiency (based on tests on indexes, including the Romanian BET-C index) is lower than in Croatia, the Czech Republic, Hungary, or Serbia but higher than the one for Bosnia-Herzegovina, Montenegro or Russia.

The investors seem to take into account the fundamentals in their decision-making process. Regarding the Romanian capital market investors' forecasting abilities, comparatively to previous studies, performed some years ago, the improvement in the level of efficiency should be noted. For instance, Dragotă and Mitrică (2004) exposed their doubts regarding the market's pricing ability (the coincidence between the intrinsic value of assets and their prices). Our investigation suggests that, after some years later from this study, investors appear to integrate new information and also their expectations regarding the values of some macroeconomic indicators in the prices of financial assets. 
Victor Dragotă, Dragoş Ştefan Oprea, Laura Obreja Braşoveanu

\section{Conclusions}

Our study analyses if the current return of stock market is associated with past, contemporaneous or future variation of different macroeconomic variables. The results suggest that the most important dependence is for the synchronous values of indicators. They can suggest a lower degree of expectancy of future indicators: publication of indicators appears more as a surprise. This type of reaction can be interpreted also as incapacity to predict future levels of indicators, because the movements of stock market index seem to be explained to the largest extent by the unanticipated movements of macroeconomic variables. Secondly, for some macroeconomic variables, the capital market might anticipate the future events (and news). These results confirm that the stock market index includes some expectations regarding the future macroeconomic variables. Finally, for some other macroeconomic variables, the capital market might react to the news with a lag.

The investors seem to integrate slowly this information (a lagged reaction). This can be a pessimistic result in the light of EMH, giving some clues for an active portfolio management. However, this association between past levels of macroeconomic variables and current values of market index can be the result of the manner some investors make predictions, based on the past levels of indicators (as suggested by Greenwood and Shleifer 2014 for US capital market).

Agents might have different channels in searching for new information and, even, might interpret it differently. For this reason, depending on the macroeconomic variable, the prices can integrate information with a lag or can be a predictor of future news.

\section{ACKNOWLEDGEMENTS}

This work was co-financed from the European Social Fund through Sectoral Operational Programme Human Resources Development 2007-2013, project number POSDRU/107/1.5/S/77213, "Ph.D. for a career in interdisciplinary economic research at the European standards". This work was partially financed by CEFIMO. The authors wish to thank Radu Ciobanu, Andreea Curmei-Semenescu, Claudiu Herțeliu, Carmen Lipară, Daniel Traian Pele, and Elena Țilică for their helpful comments. We also thank to the participants of the FIBA (Bucharest, 2013) and SSEM-EMU (Famagusta, 2013) Conferences for their useful comments. The remaining errors are ours.

\section{REFERENCES}

[1] Anghelache, G.;Kralik, L.I.; Acatrinei, M.; Pete, S. (2014), Influence of the EU Accession Process and the Global Crisis on the CEE Stock Markets: A Multivariate Correlation Analysis. Romanian Journal of Economic Forecasting 17(2), 35-52;

[2] Asprem, M. (1989), Stock Prices, Asset Portfolios and Macroeconomic Variables in Ten European Countries. Journal of Banking \& Finance 13 (4-5), 589-612; 
Market Efficiency, Predictions and Returns

[3] Boyd, J.H.; Hu, J.; Jagannathan, R. (2005), The Stock Market's Reaction to Unemployment News: Why Bad News is Usually Good for Stocks. Journal of Finance 60 (2), 649-672;

[4] Cruz, M.; Walters, B.(2008), Is the Accumulation of International Reserves Good for Development?.Cambridge Journal of Economics, 32(5), 665-681;

[5] Dragotă, V.; Mitrică, E.(2004), Emergent Capital Markets' Efficiency: The Case of Romania. European Journal of Operational Research, 155(2), 353-360; [6]Dragotă, V.; Țilică, E.V. (2014), Market Efficiency of the Post Communist East European Stock Markets. Central European Journal of Operations Research, 22(2), 307-337;

[7] Fama,E.F.(1970), Efficient Capital Market: A Review of Theory and Empirical Work. Journal of Finance, 25(2), 34-105;

[8] Fama, E.F.(1981), Stock Returns, Real Activity, Inflation, and Money. American Economic Review, 71(4), 545-565;

[9] Greenwood, R.M.; Shleifer, A.(2014), Expectations of Returns and Expected Returns. The Review of Financial Studies, 27(3), 714-746;

[10] Hanousek, J.; Kočenda, E.; Kutan, A.M. (2009), The Reaction of Asset Prices to Macroeconomic Announcements in New EU Markets: Evidence from Intraday Data. Journal of Financial Stability, 5(2),199-219;

[11] Hong, H.; Stein, J.C.(2007), Disagreement and the Stock Market. Journal of Economic Perspectives, 21(2), 109-128;

[12] Hunter, D.M.(2006), The Evolution of Stock Market Integration in the Post-Liberalization Period -A Look at Latin America; Journal of International Money and Finance, 25(5), 795-826;

[13] Lakonishok, J.; Shleifer, A.; Vishny, R.W.(1994), Contrarian Investment, Extrapolation and Risk. Journal of Finance, 49(5), 1541-1578;

[14] Malkiel, B.G.(2003), The Efficient Market Hypothesis and Its Critics. Journal of Economic Perspectives, 17(1), 59 - 82;

[15] Mankiw, G.N.(2010), Macroeconomics, $7^{\text {th }}$ ed.New York: Worth Publishers; [16] Naifar, N. (2016), Do Global Risk Factors and Macroeconomic Conditions Affect Global Islamic Index Dynamics? A Quantile Regression Approach. The Quarterly Review of Economics and Finance, 61, 29-39;

[17] Pajuste, A.; Kepitis, G.; Högfeldt, P.(2000), Risk Factors and Predictability of Stock Returns in Central and Eastern Europe. Emerging Markets Quarterly: 1-18;

[18] Patra, T.; Poshakwale, S.(2006), Economic Variables and Stock Market Returns: Evidence from the Athens Stock Exchange. Applied Financial Economics, 16(13), 993-1005.

[19] Peiro, A.(2016), Stock Prices and Macroeconomic Factors: Some European Evidence. International Review of Economics and Finance 41, 287-294;

[20] Peress, J.(2014), The Media and the Diffusion of Information in Financial Markets: Evidence from Newspaper Strikes. Journal of Finance, 69(5), 20072043; 
Victor Dragotă, Dragoş Ştefan Oprea, Laura Obreja Braşoveanu

[21] Schmeling, M. (2009), Investor Sentiment and Stock Returns: Some International Evidence. Journal of Empirical Finance, 16(3), 394-408;

[22] Suhaibu, I.; Harvey, S.; Mohammed, A.(2017), The Impact of Monetary

Policy on Stock Market Performance: Evidence from Twelve (12) African

Countries; Research in International Business and Finance 42 (2017), 1372-1382;

[23] Țilică, E.V.; Oprea, D.Ș.;Ciobanu, R.(2002), The Impact of M\&A

Announcements on Stock Prices. Published in Proceedings of the $7^{\text {th }}$ International Conference Accounting and Management Information Systems; AMIS, pg. 767-

780, ISSN 2247-6245, ISSN-L 2247-6245;

[24] Vozlyublennaia, N.(2014), Investor Attention, Index Performance, and

Return Predictability. Journal of Banking \& Finance, 41, 17-35;

[25] Welch, I.; Goyal, A. (2008), A Comprehensive Look at the Empirical

Performance of Equity Premium Prediction. The Review of Financial Studies, 21(4), 1455-1508. 